\title{
DEVELOPMENT OF CULTURAL LINGUISTIC MODULE IN OPEN EDUCATION COURSES
}

\author{
DESENVOLVIMENTO DE MÓDULO LINGUÍSTICO CULTURAL EM CURSOS DE \\ EDUCAÇÃO ABERTA
}

\author{
DESARROLLO DEL MÓDULO DE LINGÜÍSTICA CULTURAL EN CURSOS DE \\ EDUCACIÓN ABIERTA
}

\author{
Galina Savelevna SAMOYLOVA ${ }^{1}$ \\ Anna Dmitrievna KOMYSHKOVA ${ }^{2}$ \\ Natalia Mikhailovna ILCHENKO ${ }^{3}$ \\ Julia Anatolievna MARININA ${ }^{4}$
}

\begin{abstract}
The article deals with the analysis of data and the development of the educational program "In Search of the National Russian Code: Educational Paths". The program is compiled according to the relevant trends in the field of proliferation and strengthening the position of the Russian language and education in Russian in the Commonwealth of Independent States and foreign countries. The authors justify the culturallinguistic content of the program by the compliance with the modern scientific and methodological trends in studying and teaching Russian as a foreign language: forming the linguistic, communicative and cultural-linguistic competence through addressing notions such as national cultural code, national mentality, cross-cultural dialogue etc. The materials of the study include the results of the questionnaire taken by the potential students in the open education course within the program "In Search of the National Russian Code: Educational Paths". The article features the analysis of 165 questionnaires by respondents from different student groups: postgraduate students, university and college teachers and schoolteachers in the Republic of Kazakhstan. The authors analyze the answers in three content blocks: motivation for education; the most relevant questions that should be included in the courses; the most efficient ways of presenting material, that is, educational technologies, forms and techniques based on which the interaction between the subjects of open courses should be built. The results of the study allow authors to make conclusions about the potential students' preferences and interests and round up the most relevant issues and popular educational technologies. Based on the study, the authors have designed the content and methodological solutions of the educational module "Man and the world as mirror of the Russian word" within the curriculum of open education courses.
\end{abstract}

\footnotetext{
${ }^{1}$ Kozma Minin Nizhny Novgorod State Pedagogical University (MININUNIVER), Nizhny Novgorod - Russia. Assistant Professor of the Department of Russian Language and Speech Culture. ORCID: https://orcid.org/00000002-1110-6930. E-mail: galasam2010@yandex.ru

${ }^{2}$ Kozma Minin Nizhny Novgorod State Pedagogical University (MININUNIVER), Nizhny Novgorod - Russia. Associate Professor of Russian and Standard of Speech and Candidate of Philology. ORCID: https://orcid.org/0000-0002-8657-4595. E-mail: filcomanka@mail.ru

${ }^{3}$ Kozma Minin Nizhny Novgorod State Pedagogical University (MININUNIVER), Nizhny Novgorod - Russia. ORCID: https://orcid.org/0000-0003-2541-5061.E-mail: ilchenko2005@mail.ru

${ }^{4}$ Kozma Minin Nizhny Novgorod State Pedagogical University (MININUNIVER), Nizhny Novgorod - Russia. Associate Professor of the Department of Russian and Foreign Philology and Candidate of Philology. ORCID: https://orcid.org/0000-0002-5996-8396. E-mail: umarinina@gmail.com
} 
KEYWORDS: Educational module. Russian as a foreign language. Linguistic competence. Communicative competence. Cultural-linguistic competence.

RESUMO: O artigo trata da análise de dados e do desenvolvimento do programa educacional "Em Busca do Código Nacional Russo: Percursos Educacionais". O programa é compilado de acordo com as tendências relevantes no campo da proliferação $e$ fortalecimento da posição da língua russa e da educação em russo na Comunidade de Estados Independentes e países estrangeiros. Os autores justificam o conteúdo linguísticocultural do programa pela conformidade com as tendências científicas e metodológicas modernas no estudo e ensino do russo como língua estrangeira: formando a competência linguística, comunicativa e cultural-linguística por meio da abordagem de tais noções e do código de cultural nacional, mentalidade nacional, diálogo intercultural etc. Os materiais do estudo incluem os resultados do questionário respondido pelos alunos em potencial do curso de educação aberta dentro do programa "Em Busca do Código Russo Nacional: Caminhos Educacionais". O artigo apresenta a análise de 165 questionários por respondentes de diferentes grupos de estudantes: estudantes de pós-graduação, professores universitários e professores da República do Cazaquistão. Os autores analisam as respostas em três blocos de conteúdo: motivação para a educação; as questões mais relevantes que devem ser incluidas nos cursos; as formas mais eficientes de apresentar o material, ou seja, as tecnologias, formas e técnicas educacionais a partir das quais deve ser construída a interação entre as disciplinas dos cursos livres. Os resultados do estudo permitem aos autores tirar conclusões sobre as preferências e interesses dos alunos em potencial e reunir as questões mais relevantes e tecnologias educacionais populares. Com base no estudo, os autores desenharam o conteúdo e as soluções metodológicas do módulo educacional "O homem e o mundo como espelho da palavra russa" dentro do currículo dos cursos de educação aberta.

PALAVRAS-CHAVE: Módulo educacional. Russo como língua estrangeira. Competência linguística. Competência comunicativa. Competência linguística cultural.

RESUMEN: El artículo trata sobre el análisis de datos y el desarrollo del programa educativo "En busca del Código Nacional Ruso: Itinerarios educativos". El programa se compila de acuerdo con las tendencias relevantes en el campo de la proliferación y el fortalecimiento de la posición del idioma ruso y la educación en ruso en la Comunidad de Estados Independientes y países extranjeros. Los autores justifican el contenido culturallingüistico del programa por el cumplimiento de las tendencias científicas y metodológicas modernas en el estudio y la enseñanza del ruso como lengua extranjera: formando la competencia lingüistica, comunicativa y cultural-lingüistica abordando tales nociones y el código cultural nacional, mentalidad nacional, diálogo intercultural, etc. Los materiales del estudio incluyen los resultados del cuestionario realizado por los estudiantes potenciales en el curso de educación abierta dentro del programa "En busca del Código Nacional Ruso: Itinerarios educativos". El artículo presenta el análisis de 165 cuestionarios por encuestados de diferentes grupos de estudiantes: estudiantes de posgrado, profesores universitarios y universitarios y profesores de escuela en la República de Kazajstán. Los autores analizan las respuestas en tres bloques de contenido: motivación por la educación; las preguntas más relevantes que deben incluirse en los cursos; las formas más eficientes de presentar material, es decir, tecnologías, formas y técnicas educativas a partir de las cuales se debe construir la interacción entre las asignaturas de los cursos abiertos. Los resultados del estudio permiten a 
los autores sacar conclusiones sobre las preferencias e intereses de los potenciales estudiantes y resumir los temas más relevantes y las tecnologías educativas populares. A partir del estudio, los autores han diseñado el contenido y las soluciones metodológicas del módulo educativo "El hombre y el mundo en el espejo de la palabra rusa" dentro del plan de estudios de los cursos de educación abierta.

PALABRAS CLAVE: Módulo educativo. Ruso como lengua extranjera. Competencia linguistica. Competencia comunicativa. Competencia cultural-lingüistica.

\section{Introduction}

\section{Problem statement}

A goal of the departmental target program "Scientific, methodological and staffing support for teaching the Russian language and the languages of the peoples of the Russian Federation" is to spread and strengthen the position of the Russian language and education in Russian in the Commonwealth of Independent States (CIS), the Republic of Abkhazia and the Republic of South Ossetia, as well as in foreign countries which are characterized by an increase in the number of comprehensive activities aimed at promoting, supporting and strengthening the position of the Russian language, as well as popularizing Russian science, culture and education. Within this direction, the program aims to "create a single electronic educational space that combines information and educational resources on the Russian language and Russian culture, as well as resources for organizing open education courses in Russian for various levels of training" (RUSSIA, 2019).

As part of this project, an educational program "In Search of the National Russian Code: Educational Paths" was developed at the Kozma Minin Nizhny Novgorod State Pedagogical University (NNSPU). This program combined courses for different categories of students from the CIS: students studying Russian as a foreign language (RFL), university teachers and schoolteachers teaching Russian or subjects in Russian. The goals of the program related to the content of the courses were to create conditions for the formation, development and improvement of competences in the field of technologies, methods and techniques of the cultural-linguistic and communicative and activity-based approach in teaching RFL, as well as the formation, development and improvement of ideas about the national and cultural code based on concepts, verbal and artistic images that form the idea of the Russian world and cross-cultural dialogue. This determined the modular structure of the educational program2.: the thematic modules of the disciplines were built following the logic of forming various competencies: methodological, scientific-methodological and project competences in the field 
of teaching disciplines read in an RFL audience, including RFL, and linguistic, communicative and cultural-linguistic competences in the field of Russian language proficiency.

This study contains the principles of designing the cultural-linguistic module "Man and the world in the mirror of the Russian word" within the educational program "In Search of the National Russian Code: Educational Paths" according to the requirements for the relevance of the module content and its practical significance for different student categories.

\section{Justification of relevance}

The relevance of the program of open education courses "In Search of the National Russian Code" is determined by the popularity of its content which is based on modern achievements of scientific research into the Russian language, literature and culture and methods of teaching RFL. The content of the educational modules within the program is aimed at strengthening and developing cross-cultural dialogue, organizing advisory assistance in the field of mastering and studying the Russian language, Russian culture, literature for teachers of RFL or disciplines in Russian in the CIS.

The relevance of developing the cultural-linguistic content of one of the program modules is due to the tasks of popularizing the achievements of Russian science in the field of cultural-linguistic studies of the Russian language in its stylistic diversity, as well as the need to search for new methodological approaches to the study of RFL from the standpoint of cultural-linguistics (mastering the inner form of the language, its conceptual content and relevant features of communication in Russian).

\section{Novelty and significance of the study}

The novelty and significance of the research are determined by the relevant foundations of developing the content for the cultural-linguistic module of open education courses for the study of RFL. New data from a preliminary survey among potential course students are used, relevant educational needs are identified, new principles for constructing the theoretical part of the course content and practical tasks are applied in the context of digital distance learning. 


\section{Literature review}

Open education technologies are successfully implemented based on universities in the Russian Federation through digital educational platforms that make educational products available to a wide range of students including those abroad (SEMENOVA et al., 2018; TITOVA, 2015; DNEPROVSKAYA; SHEVTSOVA, 2019). At present, digital remote technologies, in particular, the resources of the Massive open online courses (MOOC), with the help of which the courses "In Search of the National Russian Code: Educational Paths" are organized, have proven to be an efficient way of organizing the educational process, especially within the framework of open education. Despite the existing shortcomings (ZAKHAROVA; TANASENKO, 2019), the capabilities of this platform are suitable for developing courses in RFL on a cultural-linguistic content basis.

When developing the educational module "Man and the world in the mirror of the Russian word", one considered the notion that language was not only a systemic-structural formation, the most important means of human communication but also an instrument for cognition, a phenomenon of social culture, a symbol of national identity and self-expression and the embodiment of the Russian mentality (PAVLOV, 2011; RADBIL, 2013). The existing cultural-linguistic works have repeatedly confirmed the importance of the linguistic and cultural component in teaching RFL at any level (VERESHCHAGIN; KOSTOMAROV, 1990; GUZMAN, 2018). National mentality, values and assessments are inevitably reflected in linguistic units, and this knowledge is necessary both for the formation of the communicative competence of foreign students mastering the Russian language and for the improvement of the professional skills of teachers of RFL and disciplines in Russian (BICHEVA; FILATOVA, 2018).

With this interpretation, the basic principles of teaching Russian as a native language and RFL, among others, become the complementary axiological and cultural-linguistic principles. Such approaches are not nation specific as the approaches are reflected in modern world pedagogy (PRABHU, 2011).

The development of the cultural-linguistic module of open education courses in the study of RFL is based on the pedagogical and methodological experience of the Kozma Minin NNSPU. The cultural-linguistic topics include the history of the Russian language, the business language and the language of the media and the features of the concept sphere of Russian culture. 
The cultural-linguistic approach to the analysis of linguistic material is presented in the educational and methodological textbooks "Overview of the Russian linguistic mentality" and "Conceptual analysis" by Pavlov $(2004 ; 2011)$. The researcher proposes a comprehensive methodology for studying the conceptual sphere of the Russian language considering all possible aspects of conceptual analysis. Special attention in modern research is paid to the axiological guidelines of modern pedagogical education, the development of a value attitude towards language as a part of national history, culture, and spirituality (SAMOILOVA et al., $2019 ; 2020)$. The possibilities of structuring the material of RFL lessons, including in the training of RFL teachers, are described in numerous works, including those based on the experience of teaching cultural-linguistic disciplines in Russian for foreign students at the Kozma Minin NNSPU (VERESHCHAGIN; KOSTOMAROV, 1990; KOMYSHKOVA, 2019; GROMENKO, 2019; KOLESOVA, 2013; TUEVA; EVTYUGINA, 2019).

The purpose of modern RFL teaching in the aspect of cultural linguistics is also the achievement of an educational result which implies proficiency in business Russian in various spheres of human activity: pedagogical, industrial, business, etc. Numerous modern studies (PENCHEVA, 2017; BOZHENKOVA et al., 2017) are devoted to relevant problems of Russian-language business and journalistic discourse in the aspect of RFL teaching. In the article by O.M. Kim and A.N. Shamov, the researchers substantiate the formation of a special type of competence related to the conduct of an intercultural business dispute in the field of business communication - the competence of a cross-cultural business dispute. The importance and significance of the competence are substantiated by state requirements for the organization of educational activities for additional professional programs aimed at acquiring personal experience in the studied types of activities (KIM; SHAMOV, 2019).

The development of cultural-linguistic content of the module "Man and the world in the mirror of the Russian word" of open education courses for studying RFL summarizes theoretical research and practical materials developed by the Kozma Minin NNSPU based on axiological, culturological and activity-based approaches in teaching Russian language and philological disciplines, including in a foreign audience, in the field of pedagogical education (NIKOLINA; RODIONOVA, 2014; LATUKHINA; MARININA, 2020; DZYUBA et al., 2020). 


\section{Proposed Methodology}

\section{General description}

\section{Methods}

We describe the methods for developing the educational module "Man and the world in the mirror of the Russian word" based on studying the needs of potential students of different categories: higher education teachers who teach disciplines in Russian, teachers in national schools teaching RFL and students of Russian.

To study educational needs, we used a questionnaire survey method that included questions with one or multiple answers, as well as open-ended questions. The respondents filled out the Internet survey form in convenient conditions. At the same time, the respondents were shown in advance the annotations of educational modules included in the open education courses "In Search of the National Russian Code: Educational Paths".

The questions offered in the questionnaire were related to several aspects necessary for the development of an educational product.

1. Motivation to learn:

- in your opinion, why do you need to take educational courses in Russian?

- your expectations from the open education course in Russian.

2. Teaching technologies:

- what forms of education, in your opinion, are the most productive for the course?

- your expectations from the open education course in Russian.

3. Educational content:

- name the modules that are most interesting to you;

- name the problem on which you would like to receive additional information that is not included in the proposed course modules;

- your expectations from the open education course in Russian. 


\section{Purpose of the study}

The purpose of the study is to find the principles of designing the educational module of open education courses in the Russian language. The questionnaire survey is aimed at identifying the needs of potential students of open education courses: determining motivation (goals and tasks that students expect to be solved within the courses), determining the most pressing issues that should be included in the course content, establishing the most effective ways of presenting the material, i.e., educational technologies, forms and techniques based on which the interaction between the subjects of open courses should be built. Based on the results of the study, training modules were designed on the digital platform of open education at the Kozma Minin NNSPU.

\section{Participants and location}

There were 165 participants in the study - post-graduate students, university and college teachers and schoolteachers in the Republic of Kazakhstan. The distribution by employment type is presented in Fig. 1.

Figure 1 - Distribution of respondents by employment type (\%)

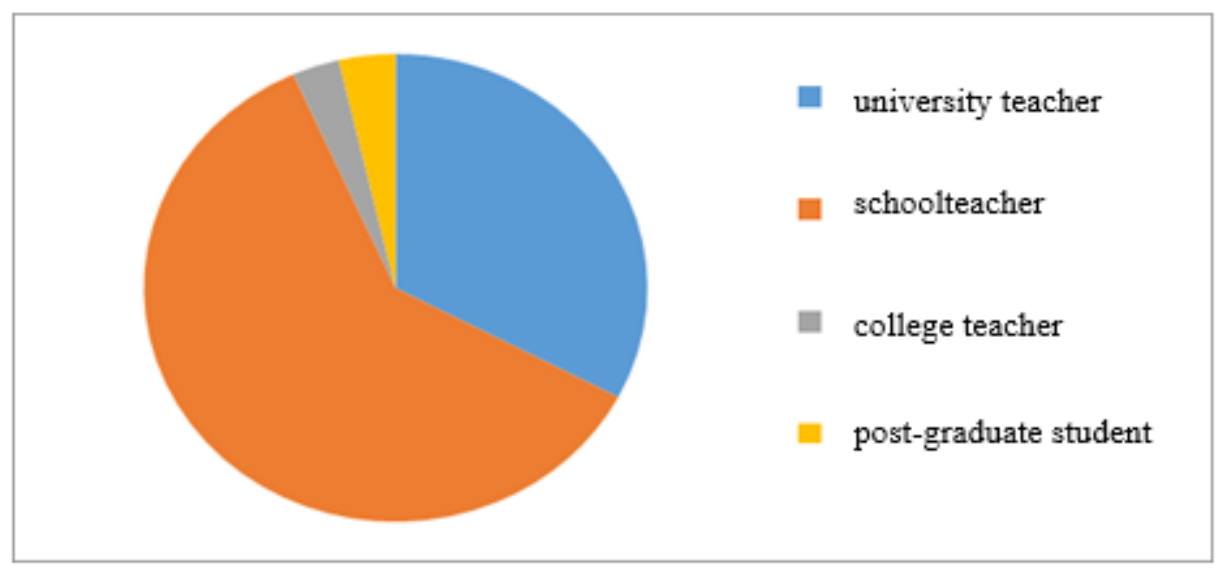

Source: Prepared by the authors

\section{Result analysis}

\section{Results of studying educational needs}

To identify the motivational component of educational needs, the respondents were offered the following answer options: 
- systematization and broadening of knowledge;

- formation of new competences;

- the need to confirm the qualification category;

- acquaintance with new pedagogical ideas and technologies;

- new contacts with fellow specialists;

- preparation for work in the context of updating the content of education.

The answers were distributed as follows (Fig. 2).

Figure 2 - Distribution of respondents according to the selected educational goals (value)

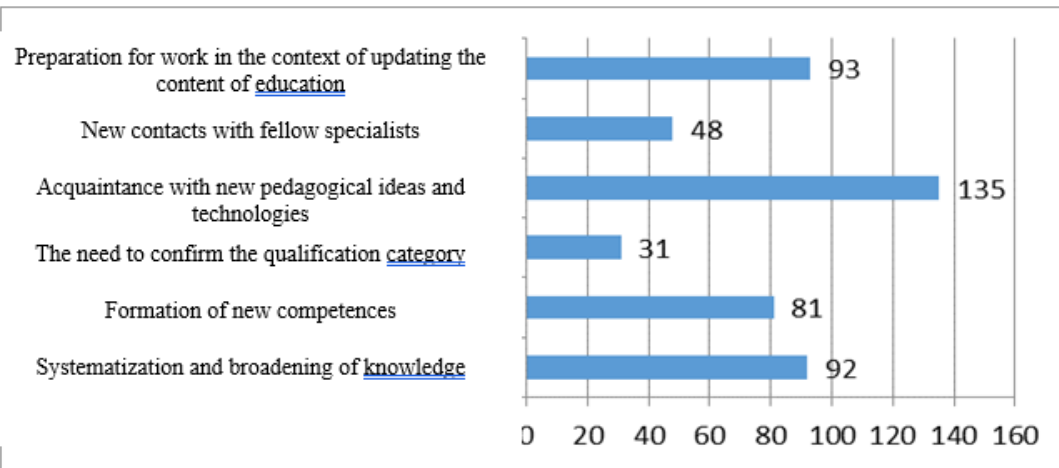

Source: Prepared by the authors

We should note that with the possibility of multiple choice, out of 165 questionnaires, 24 contained a single selected option: "acquaintance with new pedagogical ideas and technologies", 17 answers showed a combination of four answers: "systematization and broadening of knowledge", "formation of new competences", "acquaintance with new pedagogical ideas and technologies", "preparation for work in the context of updating the content of education ", and 14 questionnaires contained all six proposed answer options.

The results allowed us to conclude that the most relevant motivation for course participants is to increase their methodological competence and search for new ideas for teaching.

The identification of preferred technologies and teaching methods in open education courses was carried out through the question about the preferred work forms. The answers were distributed as follows (Fig. 3). 
Figure 3 - The distribution of respondents according to the preferred work forms in open education courses (value)

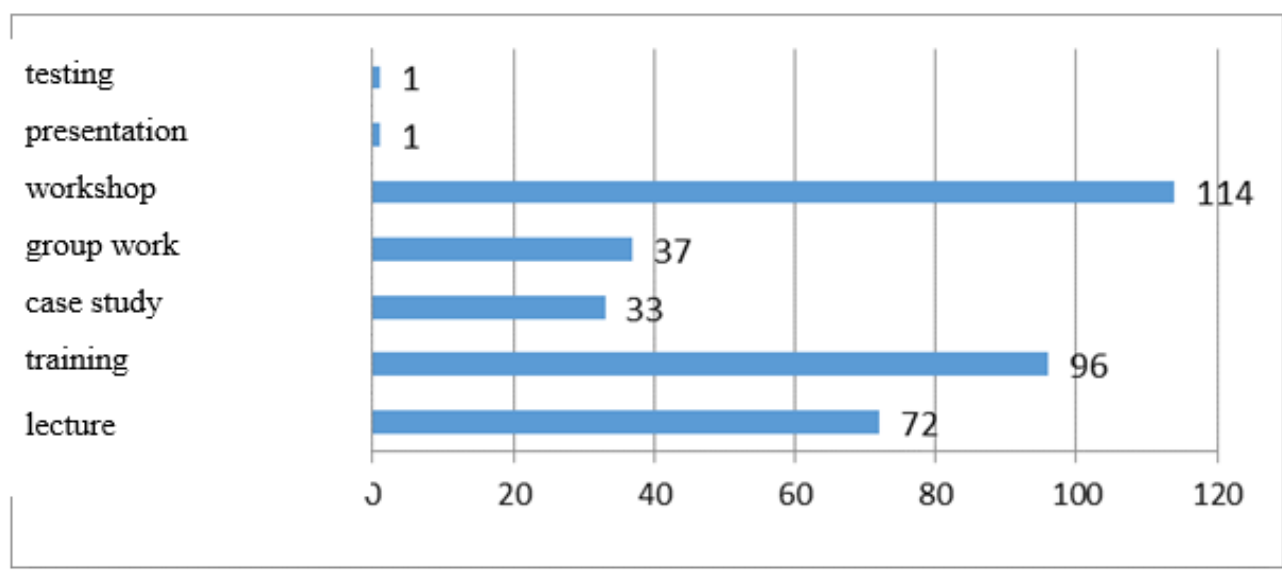

Source: Prepared by the authors

Based on the results, the most preferable were the forms of the workshop and training, i.e. types of classes that involve demonstrating pedagogical skills and mastering practical skills in the field of learning and teaching RFL. Such distribution correlates with the predominant motivation of the participants according to the research results - an increase in methodological competence. However, for distance courses, this also presents a certain difficulty, since both the workshop and the training assumes exclusively interactive work in real time.

The results of the research into the needs for the content of open education courses were distributed as follows (Fig. 4).

Figure 4 - The most interesting module of open education courses according to the survey (value)

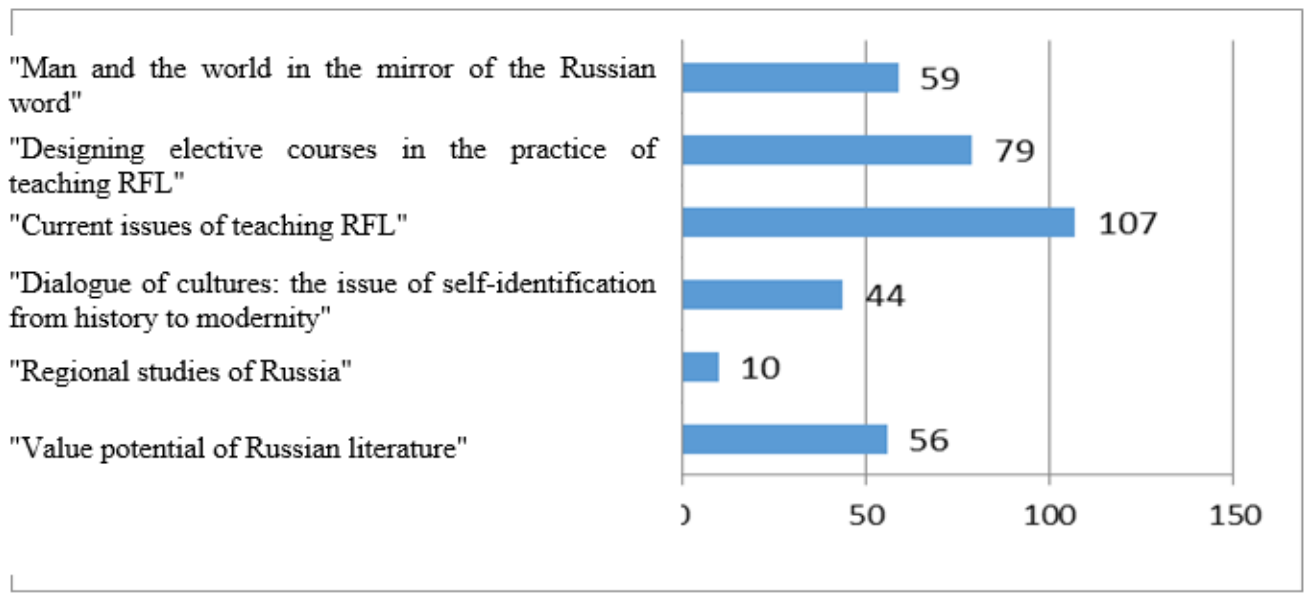

Source: Prepared by the authors 
The answers to the open-ended question "Name the problem on which you would like to receive additional information that is not included in the proposed course modules" showed some thematic consistency. Based on the analysis of the answers, we identified trends in the educational needs of potential students.

1. Methods of teaching RFL and disciplines in Russian. Examples of answers: "New technologies in teaching", "Efficient and simple methods of teaching RFL", "Experience of teaching RFL in the Chinese audience", "Methods of efficient teaching of RFL", "Formation of new competences in teaching Russian language and literature", "Development of original programs in the Russian language and literature", "Information and communication technologies in teaching the Russian language", "Innovative technologies in teaching the Russian language".

2. New approaches to teaching Russian in the context of distance learning. Examples of answers: "Teaching in a distance learning environment", "Criteria for assessing students' knowledge during distance learning", "Available teaching methods in distance learning", "Designing electronic textbooks, video lessons", "Using distance platforms in language teaching".

3. Teaching the Russian language in separate groups: "Working with gifted children", "Working with underachieving students (teaching methods)", "Difficulties in working with children who do not have a Russian-speaking environment", "Inclusive education".

4. Organization of research work of students in the Russian language and related disciplines: "Additional materials for writing a research paper", "Topics for research projects in the subject", "Help in choosing a topic for research projects", "Organization of research activities of students in Russian language and literature in a modern context", "Scientific projects for students", "Working with students to create scientific projects in the Russian language and literature", "Project activities in literature lessons, integration of literature and other humanities", "Formation of the research culture of students", "How to increase the scientific potential of students".

5. Development of the culture of Russian speech and functional literacy in students: "Development of speech culture of students", "Formation of language culture and development of functional literacy in students", "Formation of communication skills in students during Russian lessons", "Teaching students to the Russian language for the development of speech".

6. Formation of general competences of students in the process of teaching RFL: "On the role of cognitive mechanisms in the formation of key competencies", "Formation of 
mental processes in children in the practice of teaching RFL", "Development of critical thinking in Russian lessons".

7. Russian language in the aspect of cultural-linguistics: "The place of language in the modern world", "The cultural-linguistic aspect of the study of linguistic units", "Ethnolinguistics", "Cross-cultural communication", "Russian literature".

The open education course program on RFL for students from CIS developed at the Kozma Minin NNSPU meets these needs.

\section{Designing the module "Man and the world in the mirror of the Russian word"}

The program of open education courses "In Search of the National Russian Code: Educational Paths" has a modular structure united by common logic. Each module includes three to five disciplines, allowing both to use the module as an independent program and select an individual educational trajectory for various groups of students according to their professional interests and level of Russian language proficiency.

The objectives of this study are to demonstrate the principles of developing a program module "Man and the world in the mirror of the Russian word". The content of the module and the choice of forms for presenting educational material are dictated by the need to satisfy the previously studied needs of potential students. The disciplines of the module are of a linguistic and cultural nature, on the one hand. On the other, the disciplines contain the results of the practical work of teacher-developers in the field of teaching philological disciplines in Russian in a foreign language audience, i.e., can be used as a source of materials of methodological value for teachers in training.

The module includes the following disciplines:

1. History of the Russian language in the functional aspect $\left(9^{\text {th }}-21^{\text {st }}\right.$ cent.).

2. Conceptual frameworks of Russian culture.

3. Language of the modern mass media in Russia.

4. Business Russian.

5. Project work in Russian classes (from teaching experience).

The variety of content of disciplines with a common approach makes it possible to satisfy the needs identified during the study of the educational needs of potential students. Thus, the discipline "History of the Russian language in the functional aspect $\left(9^{\text {th }}-21^{\text {st }}\right.$ cent.)" contains information on the formation of the stylistic system of the Russian language from 
ancient times to the present day which not only broadens the linguistic and cultural knowledge of students but also contributes to deeper mastery of communicative competence in the Russian language (assumes the formation of greater awareness in the use of language, culture of Russian speech, stylistic traditions and functional literacy).

The discipline "Conceptual frameworks of Russian culture" is based on the scholarly achievements of modern Russian studies in the field of conceptual studies of the language semantics, i.e., corresponds to a thematic query about linguistic and cultural information about the Russian language. However, the discipline includes not only lectures but also methodically useful examples of seminars and practical classes in RFL built around key concepts of the Russian language (for example, "Woman in Russian", "Conscience in Russian", etc.). From these examples, students can learn specific teaching materials and principles of working with concepts of the Russian language in the classroom.

The disciplines "Language of the modern mass media in Russia" and "Business Russian" cover the current state of the Russian language in the field of public relations and business which is always relevant among students of RFL. Based on the identified request for the formation of the culture of Russian speech, functional literacy, the content of the disciplines was designed in such a way as to simultaneously contribute to the formation of the required skills. In addition to relevant theoretical information and a list of useful resources, the courses contain practical tasks that foster the development of functional literacy, deepen knowledge of the language of journalism, business etiquette and develop the skills of efficient communication in Russian.

The discipline "Project work in Russian classes (from teaching experience)" contains the principles of designing projects in the classroom, examples of project work implemented in the practice of the course developers and tasks for independent work of students. This discipline is the most practice-oriented, which meets several previously identified trends regarding the methodology of teaching RFL, teaching Russian in certain groups (such as gifted children, underachieving students, persons with disabilities), organization of research work for students.

When studying the discipline, lectures and practical lessons are used which include a demonstration of teaching and design technologies in the field of RFL, as well as philological disciplines taught in Russian in a foreign language audience. The main forms of implementation of this program are distance learning technologies and open online courses: digital lectures, practical tasks, an interactive glossary, a system of external links to open resources and databases. The use of the digital platform of open education allows students to 
master modern technologies of distance learning interaction through their own experience and assess the capabilities of the electronic learning environment to subsequently determine the optimal technologies for building their work in an educational institution.

\section{Conclusion}

\section{Application}

The educational module "Man and the world in the mirror of the Russian word" developed based on the research into the educational preferences of students, university teachers and schoolteachers of the Russian language in the CIS (Republic of Kazakhstan), included the disciplines of linguistic and cultural content. These disciplines made it possible to combine modern achievements of research in cultural linguistics, related both to the history of the Russian language and to modern conceptual content, with current methods of developing cross-cultural dialogue skills and designing RFL teaching from the standpoint of a communicative approach. The developed module was included in the open education program "In Search of the National Russian Code: Educational Paths" within the framework of the project "Organization of open education courses in Russian or for the study of RFL", implemented with the support of the Ministry of Education of the Russian Federation within the framework of the departmental target programs and has been successfully tested among students of open education courses from the CIS.

\section{Limitations of the study}

At present, the study is limited to the respondents of the preliminary survey: the segments of university teachers and schoolteachers of Russian and disciplines in Russian have become an indicative segment among students from the Republic of Kazakhstan. The educational needs of students studying RFL were identified based on the teaching experience of the module developed at the Kozma Minin NNSPU.

\section{Proposals for further study}

The approbation of the module "Man and the world in the mirror of the Russian word" among students from the CIS should be supplemented with a study of student satisfaction with open education courses. The study of educational needs in the field of studying RFL can 
be continued and expanded. At the same time, the developed and implemented content of the cultural-linguistic module seems relevant for other segments of the target audience of RFL students for teaching in Russian or to improve pedagogical qualifications in the field of RFL teaching.

\section{REFERENCES}

BICHEVA, I. B.; FILATOVA, O. M. Perpektivy professionalnoi podgotovki pedagogov: aksiologicheskii podkhod [Prospects of vocational training of teachers: axiological approach]. Vestnik of Minin University, v. 6, n. 2, p. 3, 2018. DOI: https://doi.org/10.26795/23071281-2018-6-2-3

BOZHENKOVA, N. A.; BOZHENKOVA, R. K.; BOZHENKOVA, A. M. Sovremennyi politicheskii diskurs: verbalnaya ekzemplifikatsiya taktiko-strategicheskikh predpochtenii [Modern political discourse: verbal exemplification of tactical and strategic preferences]. Rusistika, v. 15, n. 3, p. 255-284, 2017. DOIhttps://doi.org/10.22363/2313-2264-2017-15-3255-284

DNEPROVSKAYA, N. V.; SHEVTSOVA, I. V. Otkrytye obrazovatelnye resursy: sovremennye perspektivy [Prospects for open educational resources]. Vysshee obrazovanie $\mathbf{v}$ Rossii, v. 28, n. 8-9, p. 110-118, 2019. DOI: https://doi.org/10.31992/0869-3617-2019-28-89-110-118

DZYUBA, E. M. et al. Intellectual Resource as a Factor of Ensuring National and Cultural Security in the Conditions of the Training Course "Teacher of RFL". In: Popkova, E.; Sergi, B. (Eds.). Lecture Notes in Networks and Systems, v. 91, p. 477-483, 2020. DOI: https://doi.org/10.1007/978-3-030-32015-7 54

GROMENKO, M. Linguoculturological potential of Russian folklore in the practice of teaching RFL. Journal of science Lyon, v. 1, p. 28-31, 2019.

GUZMAN, R. T. The problems of cultural-linguistics discussed on the pages of the "Russian language studies" journal. Russian language studies, v. 16, n. 4, p. 380-397, 2018. DOI: https://doi.org/10.22363/2618-8163-2018-16-4-380-397

KIM, O. M.; SHAMOV, A. N. Formirovanie kompetentsii mezhkulturnogo delovogo spora v sfere professionalnoi delovoi kommunikatsii: soderzhatelnye i tekhnologicheskie aspekty [Formation of intercultural business dispute competence in the sphere of professional business communication: contents and technological aspects]. Vestnik of Minin University, v. 7, n. 2, p. 2, 2019. DOI: https://doi.org/10.26795/2307-1281-2019-7-2-2

KOLESOVA, D. V. Sposoby prezentatsii natsionalnykh kontseptov na uroke russkogo yazyka kak inostrannogo [Means of national concepts presentation at the lessons of RFL]. In: Russkii yazyk v sovremennom mire: traditsii i innovatsii v prepodavanii russkogo yazyka kak inostrannogo i v perevode [Russian in the modern world: traditions and innovations in teaching RFL and in translation]. Moscow: School of translation and interpretation (faculty) Lomonosov Moscow State University, 2013. p. 94-100. 
KOMYSHKOVA, A. D. Kontsept "muzhchina" v praktike prepodavaniya russkogo yazyka kak inostrannogo [The concept "man" in the practice of teaching RFL]. In: ZAKHAROVA, V.T. (Ed.). Filologicheskii dialog: collected research articles. Nizhny Novgorod: Kozma Minin Nizhny Novgorod State Pedagogical University, 2019. p. 195-204.

LATUKHINA, A. L.; MARININA, Y. A. Professionalnyi portret prepodavatelya russkogo yazyka kak inostrannogo: kompetentnostnyi podkhod [Professional portrait of a teacher of RFL: a competence-based approach] Vestnik of Minin University, v. 8, n. 4, p. 4, 2020. DOI: https://doi.org/10.26795/2307-1281-2020-8-4-4

NIKOLINA, V. V.; RODIONOVA, E. L. Kulturologicheskii podkhod v kontekste innovatsionnykh protsessov $\mathrm{v}$ obrazovanii [The culturological approach in the context of innovative processes in education]. Nizhegorodskoe obrazovanie, v. 2, p. 104-111, 2014.

PAVLOV, S. G. Kontseptualnyi analiz [Conceptual analysis]: educational and methodological textbook. Nizhny Novgorod: Nizhny Novgorod State Pedagogical University, 2004. $36 \mathrm{p}$.

PAVLOV, S. G. Osnovy russkogo yazykovogo mentaliteta [Overview of the Russian linguistic mentality]: educational and methodological textbook. Nizhny Novgorod: Nizhny Novgorod State Pedagogical University, 2011. 179 p.

PENCHEVA, A. RETUR - innovatsionnyi resurs dlya obucheniya russkomu yazyku rabotnikov turizma $\mathrm{v}$ stranakh ES [RETOUR - an innovative Russian language training resource for tourism workers in the EU]. Russian Journal of Linguistics, v. 21, n. 3, p. 635$652,2017$.

PRABHU, N. K. Human values in education: reflecting on the core. International Research Journals, v. 2, n. 12, p. 1727-1732, 2011. Available:

https://www.interesjournals.org/articles/human-values-in-education-reflecting-on-thecore.pdf. Access: 10 Jul. 2020.

RADBIL, T. B. Osnovy izucheniya yazykovogo mentaliteta [Overview of studying linguistic mentality]: a textbook. Moscow: Flinta, Nauka, 2013.328 p.

RUSSIA. Order of the Ministry of Education of Russia No. R-60. "Ob utverzhdenii vedomstvennoi tselevoi programmy "Nauchno-metodicheskoe, metodicheskoe i kadrovoe obespechenie obucheniya russkomu yazyku i yazykam narodov Rossiiskoi Federatsii" [On the approval of the departmental targeted program "Scientific and methodological, methodological and staffing support of teaching the Russian language and the languages of the peoples of the Russian Federation"]", May 16, 2019. Available: https://docs.edu.gov.ru/document/945997ac798972c086b17a4e4ec0e126/download/1512/. Access: 10 Jul. 2020.

SAMOILOVA, G. S. et al. Aksiologicheskii potentsial drevnerusskogo i staroslavyanskogo yazykov v svyazi s problemoi formirovaniya yazykovoi lichnosti filologa [Axiological potential of the old Russian and old Slavonic languages and the problem of forming the linguistic personality of a philologist]. Lingvoritoricheskaya paradigma: Teoreticheskie i prikladnye aspekty [Linguistic and rhetorical paradigm: theoretical and applied aspects], v. 24, p. 57-63, 2019. 
SAMOILOVA, G. S. et al. Old Slavonic language as a didactic resource for developing a strong language student personality. Amazonia Investiga, v. 9, n. 29, p. 327-335, 2020.

SEMENOVA, T. V.; VILKOVA, K. A.; SHCHEGLOVA, I. A. Rynok massovykh otkrytykh onlain-kursov: perspektivy dlya Rossii [The market of mass open online courses: prospects for Russia]. Voprosy obrazovaniya, v. 2, p. 173-197, 2018.

TITOVA, S. V. MOOK v rossiiskom obrazovanii [MOOC in Russian education]. Vysshee obrazovanie v Rossii, v. 12, p. 145-151, 2015.

TUEVA, K. I.; EVTYUGINA, A. A. Ispolzovanie lingvokulturnykh kontseptov v protsesse obucheniya russkomu yazyku kak inostrannomu [The Application of Linguoculturology Concepts in the Process of Teaching Russian as a foreign language]. Sotsiokulturnoe prostranstvo Rossii i zarubezhya: obshchestvo, obrazovanie, yazyk [Sociocultural space in Russia and abroad: society, education, language], v. 8, p. 144-151, 2019.

VERESHCHAGIN, E. M.; KOSTOMAROV, V. G. Yazyk i kultura: Lingvostranovedenie v prepodavanii russkogo yazyka kak inostrannogo [Language and culture: linguistic cultural studies in teaching RFL]. 4. ed. Moscow: Rus. yaz., 1990. 246 p.

ZAKHAROVA, U. S.; TANASENKO, K. I. MOOK v vysshem obrazovanii: dostoinstva i nedostatki dlya prepodavatelei [MOOC in higher education: advantages and disadvantages for teachers]. Voprosy obrazovaniya, v. 3, p. 176-202, 2019.

\section{How to reference this article}

SAMOYLOVA, G. S.; KOMYSHKOVA, A. D.; ILCHENKO, N. M.; MARININA, J. A. Development of cultural linguistic module in open education courses. Rev. EntreLínguas, Araraquara, v. 7, n. esp. 2, e021020, 2021. e-ISSN: 2447-3529. DOI: https://doi.org/10.29051/el.v7iesp.2.15146

Submitted: 05/01/2021

Required revisions: 26/02/2021

Approved: $24 / 03 / 2021$

Published: 01/06/2021 